\title{
Correction: FSRH guideline (January 2019) Combined Hormonal Contraception
}

FSRH Guideline (January 2019) Combined Hormonal Contraception BMJ Sexual \& Reproductive Health 2019;45:1-93. doi: 10.1136/bmjsrh-2018-CHC

FSRH Guideline (January 2019) Combined Hormonal Contraception (BMJ Sexual \& Reproductive Health 2019;45:1-93) has been updated since it was published.

February 2019: in table 4, the rates for perfect use of progestogen-only pill, progestogen-only injectable and levonorgestrel intrauterine device have been corrected from $0.2,0.6$ and 0.6 to $0.3,0.2$ and 0.2 , respectively.

July 2019: in Appendix 2, condition description for breast conditions e(i) Current and e(ii), Past and no evidence of current cancer for 5 years has been corrected to e(i) Current breast cancer and e(ii) Past breast cancer, respectively.

November 2020: additional guidance has been added in the footnote of table 2 for estradiol/nomegestrol combined oral contraceptives. The footnote now reads: "Day 1 for estradiol-containing COC pill. In 'Section 12.5, Other important supporting information, another bullet point has been added to direct users to discuss health risks, 'Health risks associated with use of CHC (see Section 10) and specific advice for travel, living at altitude and having surgery (see Section 14)'.

(C) Author(s) (or their employer(s)) 2021. No commercial re-use. See rights and permissions. Published by BMJ.

BMJ Sex Reprod Health 2021;47:e2. doi:10.1136/bmjsrh-2018-CHCcorr1

Check for updates 